\title{
CYCLE TEMPO POWER SIMULATION OF THE VARIATIONS IN HEAT SOURCE TEMPERATURES FOR AN ORGANIC RANKINE CYCLE POWER PLANT USING R-134A WORKING FLUID
}

\author{
Muswar Muslim ${ }^{1,2^{*}}$, Muhammad Idrus Alhamid ${ }^{1}$, Nasruddin $^{1}$, Muhamad Yulianto ${ }^{1}$, \\ Edi Marzuki ${ }^{1}$ \\ ${ }^{1}$ Department of Mechanical Engineering, Faculty of Engineering, Universitas Indonesia, Kampus UI \\ Depok, Depok 16424, Indonesia \\ ${ }^{2}$ Department of Marine System Engineering, Universitas Darma Persada, Jl. Taman Malaka \\ Selatan, Pondok Kelapa, Duren Sawit, Jakarta 13450, Indonesia
}

(Received: April 2019 / Revised: May 2019 / Accepted: July 2019)

\begin{abstract}
The focus of this study is an experiment and simulation of an Organic Rankine Cycle (ORC) system to produce electricity. The experimental equipment consisted of four main components: fluid pumps (for refrigerant and water); a condenser as a heat exchanger to condense the working fluid; an evaporator (boiler) as a heat exchanger to evaporate the refrigerant; and an expander (turbine) as a driver to produce electricity. The expander was a modification of a scroll air conditioning (AC) compressor, with a capacity of 1-3 kilowatts and connected to the generator to produce electricity in line with the design estimate. Furthermore, based on the application of the ORC experiment in the form of a small-scale power plant, a pre-determined temperature setting was set for the heat source, ranging between 80 and $100^{\circ} \mathrm{C}$. The working fluid used in the study was R-134a. Optimum power estimation was obtained by processing the experimental result data using a software cycle tempo simulation that measured several electrical power outputs between 1.76 and 2.74 kilowatts.
\end{abstract}

Keywords: Expander; Evaporator; Condenser; Cycle Tempo; Organic Rankine Cycle

\section{INTRODUCTION}

Development research on small-scale electricity generation using Organic Rankine Cycle (ORC) system technology has become increasingly prevalent, as seen in the rise in scientific articles on ORC research worldwide. For example, researchers from Belgium, Quoilin et al. (2010), examined the power plant of an ORC system with HCFC-123 working fluid by performing calculation analysis using a numerical system. Chinese researchers Shao et al. (2017) investigated an ORC power plant that also used R-123 as the working fluid on the micro radial flow turbine. Other researchers from Thailand, Sonsaree et al. (2018), examined an ORC integrated with a solar collector as a heat source. A further study by Amicabile et al. (2015) used exhaust heat from diesel engines as a heat source. It is apparent that experiments related to developing ORC for small-scale plant applications have attracted the attention of enthusiastic scientists all around the world. An ORC plant review by Muslim et al. (2015) explains the development of test rigs from the ORC system, while further research by Muslim et al. (2017) focused on the design of the dimensions of the reservoir required to produce hot water to

\footnotetext{
*Corresponding author's email: muswar_2000@yahoo.com, Tel. +62-21-7270032, Fax. +62-21-7270033 Permalink/DOI: https://dx.doi.org/10.14716/ijtech.v10i5.3067
} 
evaporate the working fluid in the evaporator. Riyanto and Martowibowo (2015) researched the use of electricity generators was based on the organic Rankine cycle (ORC) system. The purpose of this paper is to establish how much electricity an ORC power plant system uses by employing a cycle tempo simulation program. From the design, based on the results of experiments conducted on the focus of measurement of the main components of the ORC system, it is evident that the evaporator is one of the important components of the ORC system for the production of pressurized working vapor. This allows the pressurized steam to rotate the expander, which is a coupling gen-set for producing electricity. In this field of ORC study, several researchers have conducted ORC generation system experiments by using and modifying a scroll compressor of air conditioning (AC) in car as an expander, employing R245fa working fluid in the case of Gao et al. (2015) and Ziviani et al. (2014), and R-123 in the case of $\mathrm{Wu}$ et al. (2015) and Miao et al. (2015). In this research, the expander from the modification of the scroll AC compressor is used for cooling land vehicles. This study aims to determine the level of thermal efficiency achieved in the experiment. Its originality is the selection of an expander using a Sanden TRSE09 with R-134a working fluid, which is more environmentally friendly.

\section{METHODS}

\subsection{ORC Theory and Equations}

The research methodology used defined several equations specifically devoted to estimating the results of the data processing associated with the experiment ORC on small-scale power plants for organic Rankine cycle (ORC) technology. First, an explanation will be given of the theory of the ORC work process using a P-h diagram, with the working fluid employed being R-134a, as shown in Figure 1.

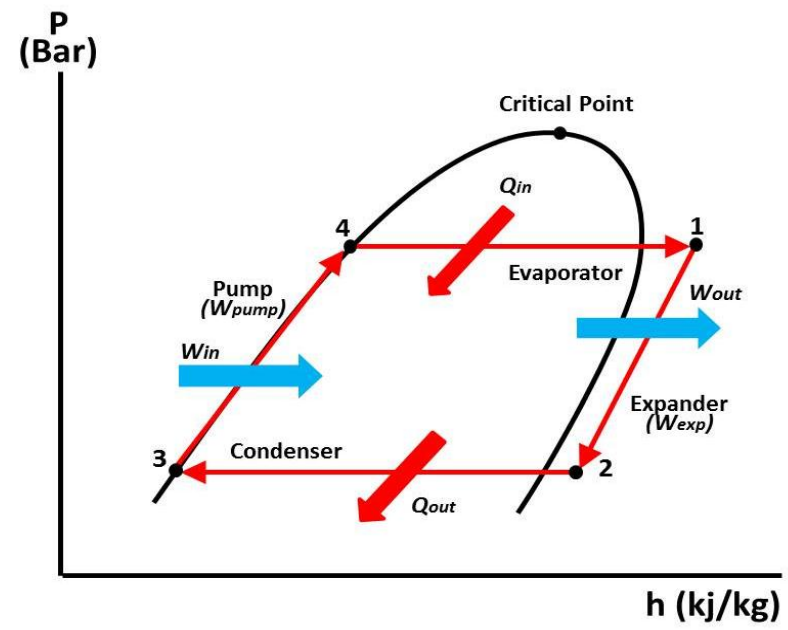

Figure 1 ORC Cycle

Figure 1 explains the process of the ORC system, showing that at point 3 the working fluid pump draws the fluid out of the condenser, which then flows into the evaporator. The pump work rate equation is as follows:

$$
\begin{gathered}
W_{\text {Pump }}=\mathrm{m}_{\text {fluid }} \cdot\left(h_{\text {Pump.out }}-h_{\text {Pump.in }}\right) /\left(\eta_{\text {pump }}\right) \\
\text { or } \\
W_{p=} h_{4}-h_{3}
\end{gathered}
$$


where $W p$ is the power that enters each mass unit by flowing through the pump.

The refrigerant then evaporates in the heat exchanger, which is combined with a heater package to produce hot water. This will release the heat in the flow through refrigerant pipes in the evaporator at positions 1 and 4, enabling the refrigerant to change its phase from liquid to gas. The process of changing the thermal form is the balance of mass and energy given by the following equation:

$$
Q_{\text {in }}=h_{2}-h_{3}
$$

where $Q_{\text {in }}$ is the rate of heat transfer from the energy source into the working fluid per unit of mass through the evaporator; the refrigerant vapor then flows into the expander.

The refrigerant vapor coming from the evaporator at point 1 is at high temperature and high pressure. It will expand, rotating the expander to produce work, and will then flow to the condenser at point 2 with relatively low vapor pressure.

The heat transfer in on the expander is not taken into account, so the equilibrium rate of massenergy around the expander is given by the following equation:

$$
W_{\text {exp }}=h_{1}-h_{2}
$$

where $W_{\text {exp }}$ represents the rate of work produced per unit of steam mass through the expander.

In the condenser, at positions 2 and 3, the heat is ejected through the cooling water pipe at a certain temperature and with a certain amount of heat. The energy equation in the condenser is given as follows:

$$
Q_{o u t}=h_{1}-h_{4}
$$

where $Q_{o u t}$ is the rate of energy transfer from the working fluid to the cooling water per unit of fluid mass that works through the condenser. Thermal efficiency is used to measure the amount of energy transferred into the refrigerant by employing the following equation:

$$
\eta_{t h}=\left(w_{\exp }-w_{p}\right) / Q_{\text {in }}=\left(\left(h_{1}-h_{2}\right)-\left(h_{4}-h_{3}\right)\right) /\left(h_{1}-h_{4}\right)
$$

The heat is then released into the environment, so input heat $\left(Q_{i n}\right)$ is essential to the process of increasing heat transfer, while thermal efficiency is reduced. This condition exists due to irreversibility in the pump and expander, meaning the work $\left(w_{p}\right)$ needed is greater and the expander work $\left(w_{\text {exp }}\right)$.

\subsection{Experiment Design}

The design of the experimental equipment used in the ORC system is shown in Figure 2, accompanied by a diagram of the ORC apparatus shown in Figure 3. Working fluid enters the evaporator at a given temperature, and is then converted into gas by absorbing the heat from the air in the compartment. The working fluid exits the evaporator as saturated vapor and then enters the compressor. High temperature and high pressure working fluid continues to flow into the condenser and releases heat into the environment. Some of the main ORC equipment, for instance the evaporator, requires a heat source. That used in this study was an electric heater with 1000 kilowatts of power and a maximum temperature of $100^{\circ} \mathrm{C}$; it could be set at temperatures of between $80^{\circ} \mathrm{C}$ and $100^{\circ} \mathrm{C}$. Subsequently, to change the working fluid phase in the cooling system and also called a condenser is required. 


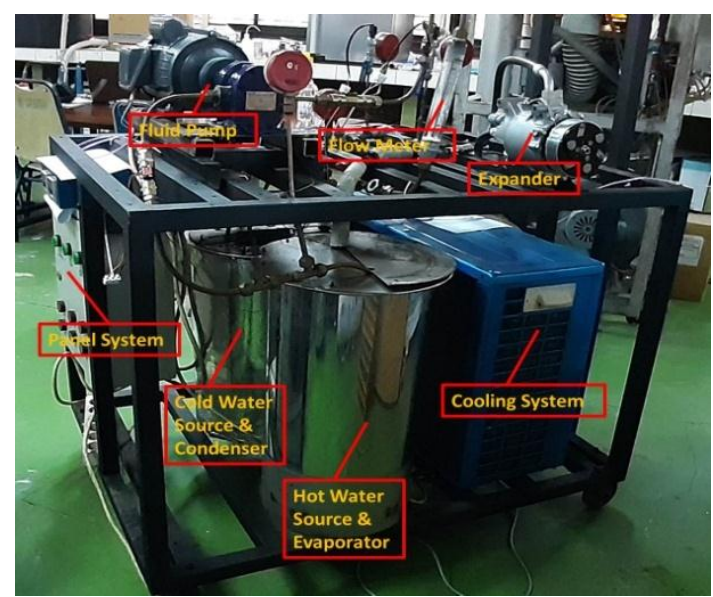

Figure 2 ORC Apparatus
The Power Generation of Organic Rankine Cycle

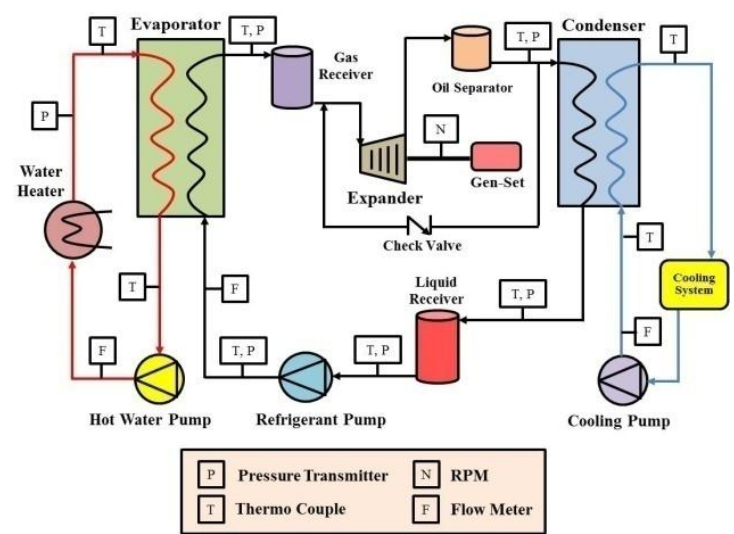

Figure 3 Diagram of ORC

The temperature in this refrigeration system can reach close to $0^{\circ} \mathrm{C}$, but for this study it was set at $20^{\circ} \mathrm{C}$, to where the goal is to adjust an ambient temperature. The expander is a main component that works as a turbine to drive a generator that will generate electricity. Oralli et al. (2011) conducted an ORC experiment using a scroll compressor type expander from a turbomachine. In this experiment, the expander used was a scroll type Sanden TRSE09. This type of expander is used especially in air conditioning (AC) systems commonly found in cars and can be modified into an expander that drives a generator to produce electricity. The pump used to drain the working fluid in the ORC system is a pump type that is commonly employed for vegetable oil. This working fluid pump is coupled with an electric motor that can adjust to the specifications of other electric motor rotation rates, varying between 500 and $3000 \mathrm{rpm}$. In this ORC experiment, the working fluid pump was the main component of the ORC system used to drain the working fluid to from all the major components of the ORC system, including the evaporator, expander and condenser. The flow of working fluid allows the main components to work according to their respective functions. The evaporator selected was a type of Plate Heat Exchanger (PHE), which serves to convert the working fluid from liquid to a vapor or gas state. It works by transferring heat energy from the hot water source to the working fluid. The work from a heat source is was fresh water which has been heated by a stainless steel heater placed in a water reservoir. The dimensions of the drum including heater with dimention is $60 \mathrm{~cm}$ high with a diameter of $50 \mathrm{~cm}$. The water heater could be set up to $100^{\circ} \mathrm{C}$. This heating device worked to heat the fresh water, which was used to provide heat to the working fluid to change its liquid state into gas at a certain temperature and display the pressure count on the installed measuring instrument. To enable the fluid to work properly for a refrigeration system was installed in one of component of the ORC experimental equipment. This cooled the fresh water that had been collected in the water reservoir drum. A water pump with an electrical capacity of 370 watts then channelled the flow of cooled water to the condenser. The setting of the cooling water temperature was based on the initial plan, which was $20^{\circ} \mathrm{C}$.

\subsection{Working Fluid Selection}

The working fluid used in the experiment was R-134a. This is generally used in a refrigeration system or air conditioning unit to reduce the temperature of the room or to freeze a liquid. In an ORC, the main function of R-134a is as a working fluid that gives momentum to the expander, thereby causing the generator to produce electricity. The specifications of the working fluid used in this experiment are given in Table 1. 
Table 1 Properties of R134a

\begin{tabular}{lc}
\hline \multicolumn{1}{c}{ Characteristic } & Conditions \\
\hline Boiling Point & $-14.9^{\circ} \mathrm{F}$ or $-26.1^{\circ} \mathrm{C}$ \\
Auto-Ignition Temperature & $1418^{\circ} \mathrm{F}$ or $770^{\circ} \mathrm{C}$ \\
Ozone Depletion Level & 0 \\
Solubility in Water & $0.11 \%$ by weight at $77^{\circ} \mathrm{F}$ or $25^{\circ} \mathrm{C}$ \\
Critical Temperature & $252^{\circ} \mathrm{F}$ or $122^{\circ} \mathrm{C}$ \\
Cylinder Color Code & Light Blue \\
Global Warming Potential (GWP) & 1200 \\
\hline
\end{tabular}

\section{RESULTS AND DISCUSSION}

From the results of the experiment, it can be seen that the temperature changes of each component of the experimental equipment in the ORC system varied according to the set temperature: $80^{\circ} \mathrm{C}, 85^{\circ} \mathrm{C}, 90^{\circ} \mathrm{C}, 95^{\circ} \mathrm{C}$ or $100^{\circ} \mathrm{C}$.

\subsection{Experiment Results}

Experiment setting at $80,85,90,95$ and $100^{\circ} \mathrm{C}$

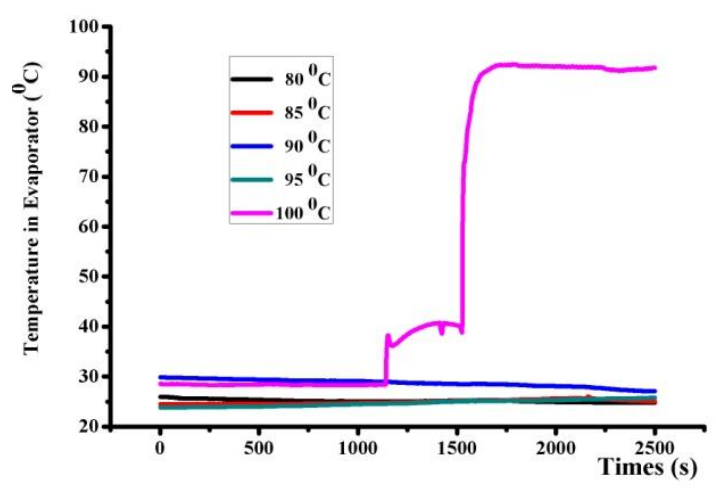

Figure 4 Temperature in Evaporator

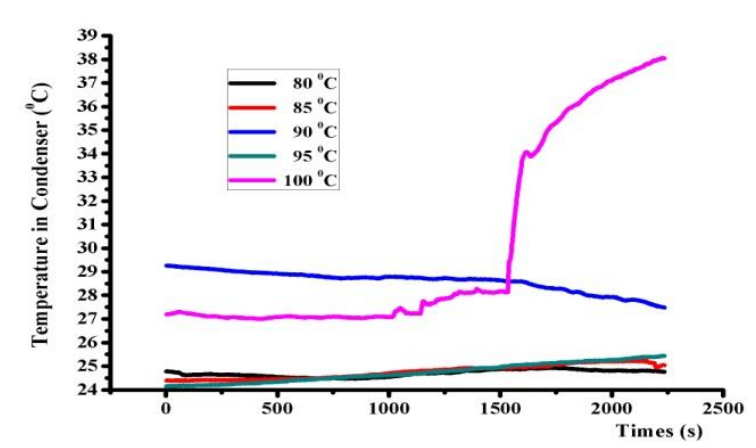

Figure 6 Temperature in Condenser

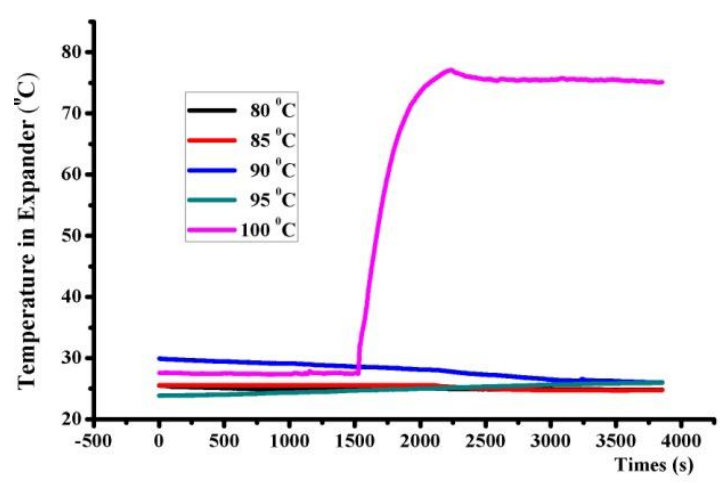

Figure 5 Temperature in Expander

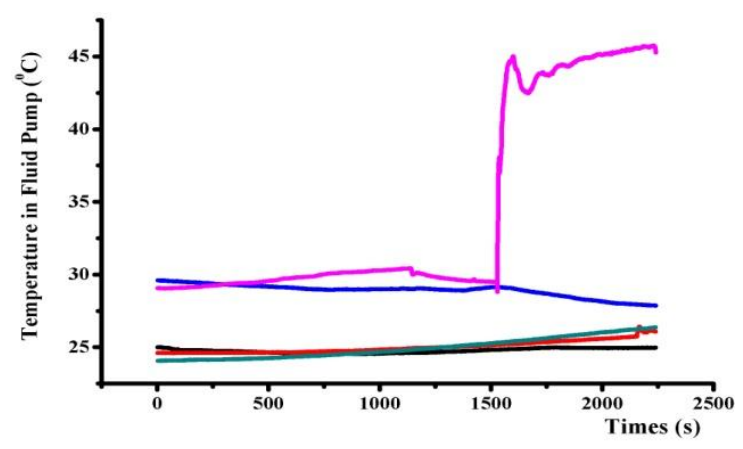

Figure 7 Temperature in Fluid Pump

From each temperature in the evaporator, which has a temperature variation of between $80^{\circ} \mathrm{C}$ and $100^{\circ} \mathrm{C}$, as shown Figure 4, the highest temperature setting chosen was $100^{\circ} \mathrm{C}$, because at this level the temperature increases over 1550 to 3500 seconds, based on the results of the measurements from result of the measuring instrument of around 90 to $92^{\circ} \mathrm{C}$ showed the pressure of the refrigerant can be greatly increased, resulting in the formation of gas in the 
working fluid, so there is a strong push into the large expander because there is high enough rotation. The temperature in the expander shown in Figure 5 is the result of data that appeared on the thermocouple display with the highest temperature setting of $100^{\circ} \mathrm{C}$ and the time position is between 1500 to 2250 seconds with the highest temperature around $75^{\circ} \mathrm{C}$. But in this position the temperature becomes somewhat lower due to the release of heat around the expander taken by the ambient temperature. Then in the next process then by setting the temperature variation from 80 to $100^{\circ} \mathrm{C}$ shown in Figure 6 that can be seen in the highest temperature settings taken is at the setting of $100^{\circ} \mathrm{C}$ shows that the graph also changes the time process when the seconds to 2250 temperatures at condenser until it can reach $38^{\circ} \mathrm{C}$. At this temperature the condition of the working fluid form turns to liquid so that it can be easily flowed by the working fluid pump to the evaporator. The last is in Figure 7 shows that the temperature at the fluid pump based on the highest temperature settings between 80 to $100^{\circ} \mathrm{C}$. And also determined that this experiment at a temperature setting of $100^{\circ} \mathrm{C}$ with temperature output data on a thermocouple display that reads around 45 to $46^{\circ} \mathrm{C}$ which occurs at 1520 to 2250 seconds. From the explanation of the four main components above which mention the process of increasing and decreasing the temperature of each of the main components, then to make a simulation to estimate the amount of power expander and generator power using software cycle tempo is the setting temperature at $100^{\circ} \mathrm{C}$. The choice of setting this temperature of $100^{\circ} \mathrm{C}$ in order to obtain high power expander and generator power.

\subsection{Analysis of Actual Experiments}

From the five temperature variations of $80^{\circ} \mathrm{C}, 85^{\circ} \mathrm{C}, 90^{\circ} \mathrm{C}, 95^{\circ} \mathrm{C}$ and $100^{\circ} \mathrm{C}$ that average temperature obtained from the ORC components includes on temperatures in evaporator, expander and condenser shown at Table 2. Based on the results of the average estimate, the most possible for the best results on the output power obtained is at a setting of $100^{\circ} \mathrm{C}$.

Table 2 Average temperature in each component of the ORC system

\begin{tabular}{ccccc}
\hline No. & $\begin{array}{c}\text { Temperature }\left({ }^{\circ} \mathrm{C}\right) \\
\text { Setting }\end{array}$ & $\begin{array}{c}\text { Average } \\
\text { Temperature in } \\
\text { Evaporator }\left({ }^{\circ} \mathrm{C}\right)\end{array}$ & $\begin{array}{c}\text { Average } \\
\text { Temperature in } \\
\text { Expander }\left({ }^{\circ} \mathrm{C}\right)\end{array}$ & $\begin{array}{c}\text { Average } \\
\text { Temperature in } \\
\text { Condenser }\left({ }^{\circ} \mathrm{C}\right)\end{array}$ \\
\hline 1. & 80 & 64.36 & 47.23 & 26.28 \\
2. & 85 & 70.91 & 55.60 & 30.71 \\
3. & 90 & 73.46 & 55.97 & 29.99 \\
4. & 95 & 88.44 & 69.96 & 28.62 \\
5. & 100 & 91.89 & 75.51 & 31.06 \\
\hline
\end{tabular}

\subsection{Results of Simulation with Cycle Tempo}

Based on the data processing variations at five temperature settings, namely from $80^{\circ} \mathrm{C}$ to $100^{\circ} \mathrm{C}$, as shown in Table 2 , the data with significant and optimum experimental results are seen in the measurement results. The parameters of the measurement results of the variation of the temperature settings are varied on the heater based on a predetermined temperature that is from $80,85,90,95$ and $100^{\circ} \mathrm{C}$. Furthermore, the data from the experimental results were entered into program simulation of cycle tempo to as certain how much expander and generator power were simulated. Then based on the simulation results of the cycle tempo with an increase in power of 2.19 kilowatts, 2.33 kilowatts, 2.47 kilowatts, 2.60 kilowatts and 2.74 kilowatts. Then for other parameter measurements is the pressure on some of the main components of the ORC system listed in the cycle tempo simulation that is the pressure on the evaporator at 12 bar and condenser is 6 bar. Both pressures in the evaporator and condenser were set to produce of optimum power in expander and gen-set. The magnitude of the flow rate of working fluid in the ORC system is $0.036 \mathrm{~kg} / \mathrm{s}$ and the flow of this working fluid greatly affects the amount of energy that occurs in heat transfer in the evaporator and condenser, as well as the magnitude of 
the flow affects the power that occurs in the expander and gen-set. The highest temperature dataset will be shown, which affects the size of the components in the ORC system by using a cycle tempo simulation program with the option at of a temperature of $100^{\circ} \mathrm{C}$ as shown in Figure 8 .

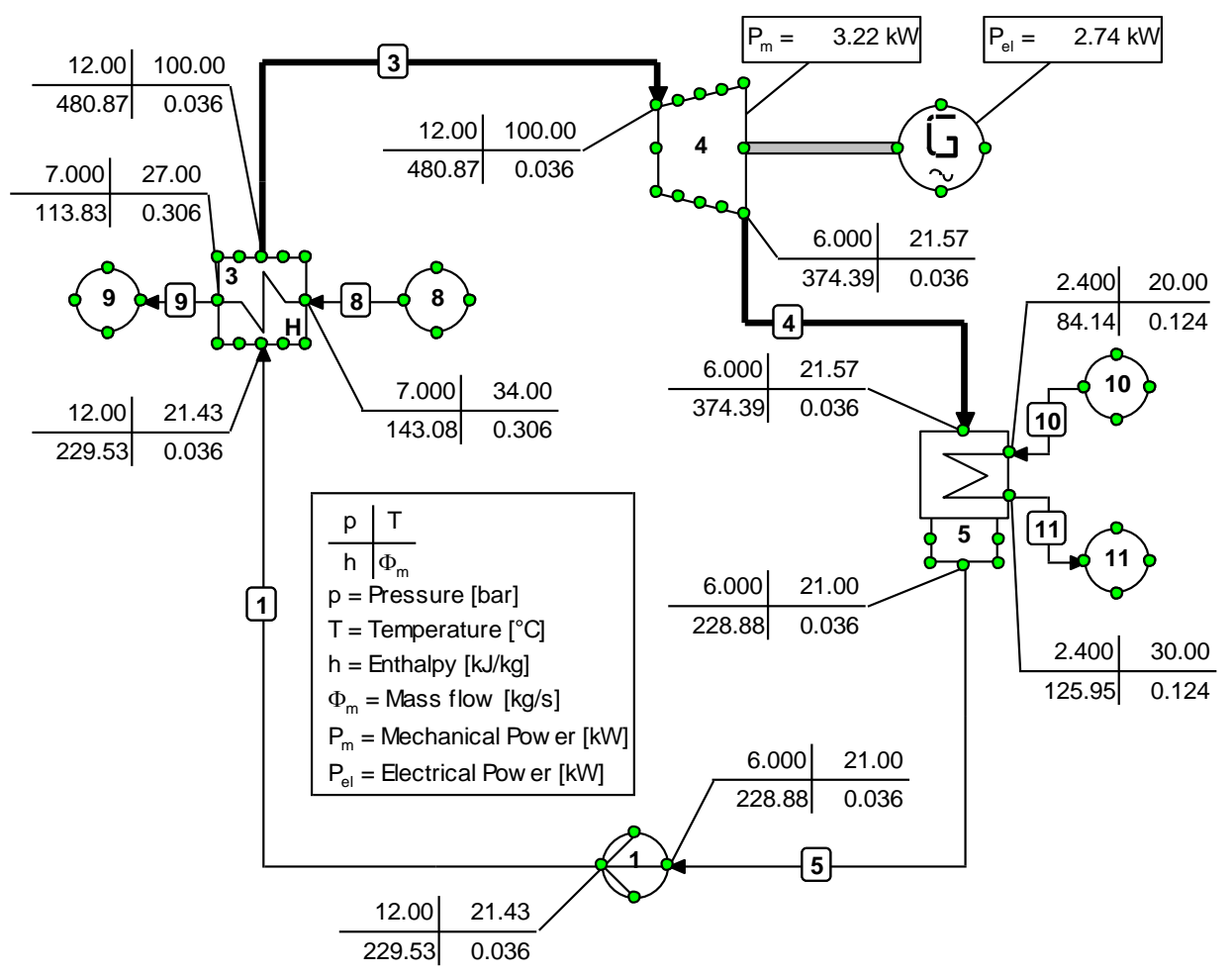

Figure 8 Simulation program of cycle tempo at $100^{\circ} \mathrm{C}$

The estimation of the cycle tempo simulation program shows that the temperature setting of $100^{\circ} \mathrm{C}$ produces estimated electrical power of 2.74 kilowatts.

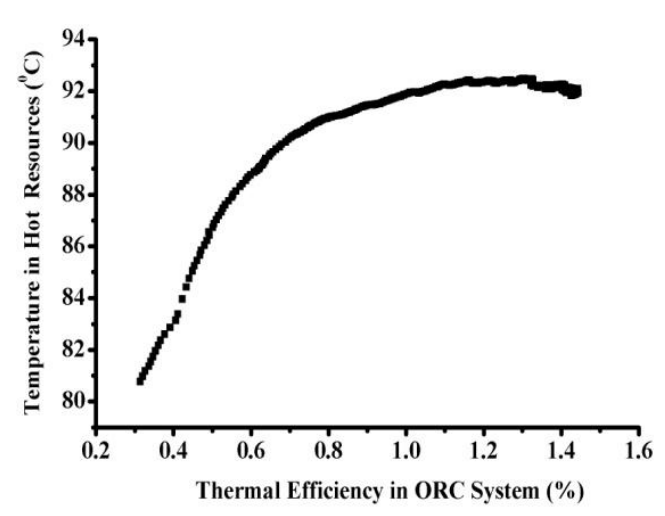

Figure 9 ORC thermal efficiency

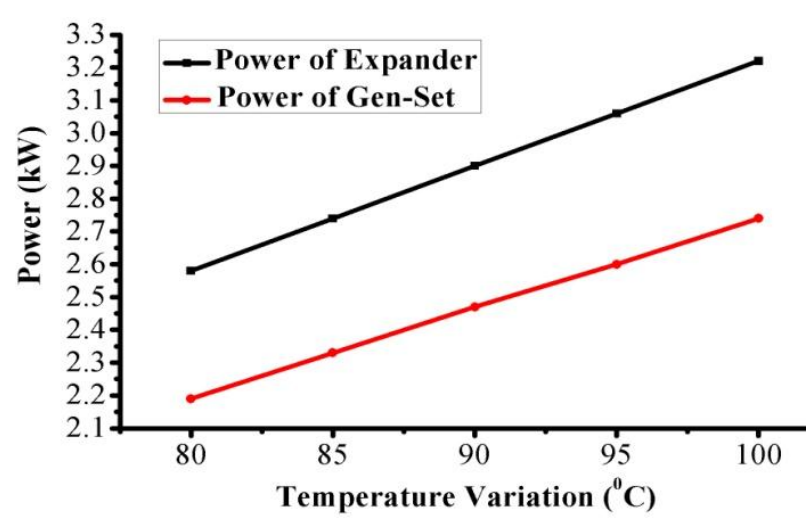

Figure 10 Power ORC with cycle tempo

Figure 9 shows that the increase in the thermal efficiency graph from $0.3 \%$ to $1.4 \%$ in the ORC system is based on the results of the processed experimental data and is accompanied by an increase in the temperature of the heat source set at $100^{\circ} \mathrm{C}$. To predict the magnitude of the expander power and the magnitude of the gen-set power calculated using the cycle tempo simulation program shown in figure 8 selected in setting from 5 temperature variations. Furthermore, the increase in expander and gen-set power based on the cycle simulation of the 
sample simulation program results is shown in Figure 10. The results of the cycle tempo simulation show that the greatest increase in expander power was 3.22 kilowatts and in gen-set power 2.74 kilowatts.

\section{CONCLUSION}

Based on the results of experiments that have been done with processed parameter data such as temperature, pressure and flowrate of working fluid that the refrigerant selected as the working fluid in this ORC system is R-134a. Determination of the variation in temperature set was at $80^{\circ} \mathrm{C}, 85^{\circ} \mathrm{C}, 90^{\circ} \mathrm{C}, 95^{\circ} \mathrm{C}$, and $100^{\circ} \mathrm{C}$ in the installed heat source equipment, and the simulation power estimated by the cycle simulation program was 2.19 kilowatts, 2.33 kilowatts, 2.47 kilowatts, 2.60 kilowatts and 2.74 kilowatts, respectively. Furthermore, the thermal efficiency that occurred during the experimental process was at a temperature setting of $100^{\circ} \mathrm{C}$ in this ORC system is $0.3-1.4 \%$.

\section{ACKNOWLEDGEMENT}

The publication of this article was supported by Universitas Darma Persada through SK Rektor number 39/KPTS/UNSADA/IX/2017.

\section{REFERENCES}

Amicabile, S., Lee, J., Kum, D., 2015. A Comprehensive Design Methodology of Organic Rankine Cycles for the Waste Heat Recovery of Automotive Heavy-duty Diesel Engines. Applied Thermal Engineering, Volume 87, pp. 574-585

Gao, P., Jiang, L., Wang, L.W., Wang, R.Z., Song, F.P., 2015. Simulation and Experiments on an ORC System with Different Scroll Expanders based on Energy and Exergy Analysis. Applied Thermal Engineering, Volume 75, pp. 880-888

Miao, J., Xu, L., Yang, X., Zou, J., 2015. Operation and Performance of a Low-temperature Organic Rankine Cycle. Applied Thermal Engineering, Volume 75, pp. 1065-1075

Muslim, M., Alhamid, M.I., Nasruddin, 2015. A review of Development of Test Rig for Organic Rankine Cycle. In: Proceeding of the $8^{\text {th }}$ International Meeting on Advances in Thermofluids (IMAT), Universitas Indonesia

Muslim, M., Alhamid, M.I., Nasruddin, Ramadian, D., Satria, Z., Marzuki E., 2017. Design of One Combination Package between Heat Exchangers and Heater for Organic Rankine Cycle Power Plant. In: The $2^{\text {nd }}$ International Tropical Renewable Energy Conference (iTREC), Bali, Indonesia

Oralli, E., Tarique, M.A., Zamfirescu, C., Dincer, I., 2011. A Study on Scroll Compressor Conversion into Expander for Rankine Cycles. International Journal of Low-Carbon Technologies, Volume 6(3), pp. 200-206

Quoilin, S., Lemort, V., Lebrun, J., 2010. Experimental Study and Modeling of an Organic Rankine Cycle using Scroll Expander. Applied Energy, Volume 87(4), pp. 1260-1268

Riyanto, H., Martowibowo, S.Y., 2015. Optimization of Organic Rankine Cycle Waste Heat Recovery for Power Generation in a Cement Plant Response Surface Methodology. International Journal of Technology, Volume 6(6), pp. 938-945

Shao, J.Z., Meng, X., Wei, X., Ma, X., 2017. Experimental Study of an Organic Rankine Cycle System with Radial inflow Turbine and R123. Applied Thermal Engineering, Volume 124, pp. 940-947

Sonsaree, S., Asaoka, T., Jiajitsawat, S., Aguirre, H., Tanaka, K., 2018. A Small-scale Solar Organic Rankine Cycle Power Plant in Thailand: Three Types of Non-concentrating Solar Collectors. Solar Energy, Volume 162, pp. 541-560 
Wu, Z., Pan, D., Gao, N., Zhu, T., Xie, F., 2015. Experimental Testing and Numerical Simulation of Scroll Expander in a Small-scale Organic Rankine Cycle System. Applied Thermal Engineering, Volume 87, pp. 529-537

Ziviani, D., Suman, A., Lecompete, S., De Paepe, M., Van Den Broek, M., Spina, P.R., Pinelli, M., Venturini, M., Beyene, A., 2014. Comparison of a Single-screw and a Scroll Expander under Part-load Conditions for Low-grade Heat Recovery ORC Systems. Energy Procedia, Volume 61, pp. 117-120 